\title{
Limb amputation by male Neotropical longhorn beetles during competition for females
}

\author{
Folke Kustvall Larsson ${ }^{1,2}$ \\ ${ }^{1}$ Adoxa Biology, Jupitervägen 13, SE-181 63 Lidingö, Sweden \\ ${ }^{2}$ Corresponding author: Folke Kustvall Larsson, e-mail: folke.k.larsson@biology.adoxa.eu
}

LARSON, F.K. Limb amputation by male Neotropical longhorn beetles during competition for females. Biota Neotrop. 10(1): http://www.biotaneotropica.org.br/v10n1/en/abstract?short-communication+bn02710012010.

Abstract: The biology and mating behaviour of the spectacularly large and brightly coloured Neotropical longhorn beetle Schwarzerion holochlorum Bates 1872 (Coleoptera: Cerambycidae) is largely unknown. For the first time I report and photographically document violent male-male competitions for females involving frequent amputations of competitors' legs and antennae.

Keywords: amputations, male-male competition, Palo Verde National Reserve, Costa Rica, longhorn beetle, Cerambycidae, mating system.

LARSON, F.K. Amputación de extremidades por parte de los escarabajos longicornios Neotropicales machos durante la lucha por las hembras. Biota Neotrop. 10(1): http://www.biotaneotropica.org.br/v10n1/pt/abstract?shortcommunication+bn02710012010.

Resumo: En gran parte, son desconocidos la biología y el comportamiento de apareamiento del escarabajo longicornios Neotropical Schwarzerion holochlorum Bates 1872 (Coleoptera: Cerambycidae), una especie espectacularmente grande y de vivos colores. Por primera vez en esta especie, relato y documento fotográficamente las luchas violentas entre machos por las hembras, incluyendo amputaciones frecuentes de las piernas y antenas del competidor.

Palavras-chave: amputaciones, lucha entre machos, Parque Nacional Palo Verde, Costa Rica, escarabajo longicornios, Cerambycidae, sistema de apareamiento. 


\section{Introduction}

In some subfamilies of cerambycid beetles, males have been reported to compete violently for females by pushing, biting, or kicking. During these antagonistic interactions, size has often been found to be beneficial (Linsley 1959, Hanks et. al. 1996, Wang \& Zeng 2004). In cerambycid harlequin beetles, Acrocinus longimanus, there is intense male competition to monopolize suitable oviposition sites. In this species males use their forelegs in fights with other males (Zeh et al. 1992). In other species, smaller challenging males have been reported successful in such combats and sometimes manages to displace larger males or gaining matings (Goldsmith et al. 1996, Ray et al. 2009). In a study by Møller \& Zamora-Muñoz (1997), antennal symmetry, rather than large size, has been found under sexual selection and a basic mating advantage in Stenurella melanura. A previous study on this species, however, indicate the importance of male size but also that ambient temperature may reverse size-dependent male mating success (Larsson \& Kustvall 1990), indicating the complexity of this cerambycid mating system.

Some studies indicate the importance of mandibles in mate competition. Thus, in cerambycid species with prognathous mandibles, mutilations among males have been reported (Linsley 1959). In the old house borer Hylotrupes bajulus and in Cerambyx welensii loss of antennal or leg segments have been observed (Fettköther 2000, López-Pantoja et al. 2008). Male courtship by biting female antennae and omissions of legs and antennae in these encounters has been observed in the subfamily Lepturinae (Michelsen 1963). Such mutilations have also occurred in other species (Linsley 1959). However, these encounters have not been described or documented at any detail.

\section{Materials and Methods}

I made all observations at a natural aggregation of Schwarzerion holochlorum (Coleoptera: Cerambycidae) on 21 December 2008, within the Palo Verde Natural Reserve, close to the OTS research station, in the Guanacaste province, Costa Rica (10 18 ' 25.92" N and $\left.84^{\circ} 48^{\prime} 35.28^{\prime \prime} \mathrm{W}\right)$. Schwarzerion holochlorum is a spectacularly large and brightly coloured metallic-green species, with males reaching $4.5 \mathrm{~cm}$ in body length, and with an antennal length 2.5 times the body length. The species occurs from Mexico through central America to Venezuela. There are two more species within the genus, occurring from Mexico to Panama.

The Palo Verde Natural Reserve is a diverse patchwork of habitats, the observation site consisting of deciduous seasonally dry forest on limestone outcrops. The canopy trees at the site were not more than $10 \mathrm{~m}$ tall, the dense shrub layer 2-4 m tall.

\section{Results and Discussion}

Beginning at 15:40 hours, males began aggregating at the trunk of a large tree inside forested habitat. One male was observed flying to the site from a distance of more than $14 \mathrm{~m}$. Five to seven males engaged in violent male-male interactions at the trunk, and a number of smaller females passively were perched around the periphery. Male encounters were frequent, and involved biting the opponent's leg, usually at the femur, then wrenching it back and forth repeatedly (Figure 1). A male able to maintain his grip would eventually remove the leg of his opponent after 1.5-3.5 minutes. Legs occasionally separated at the coxa or sometimes from below the femur, depending on where the mandibles were gripping the leg. Some of the males I observed were severely damaged, with only four intact legs. Reduced antennae in some males also suggested biting damages to antennae.
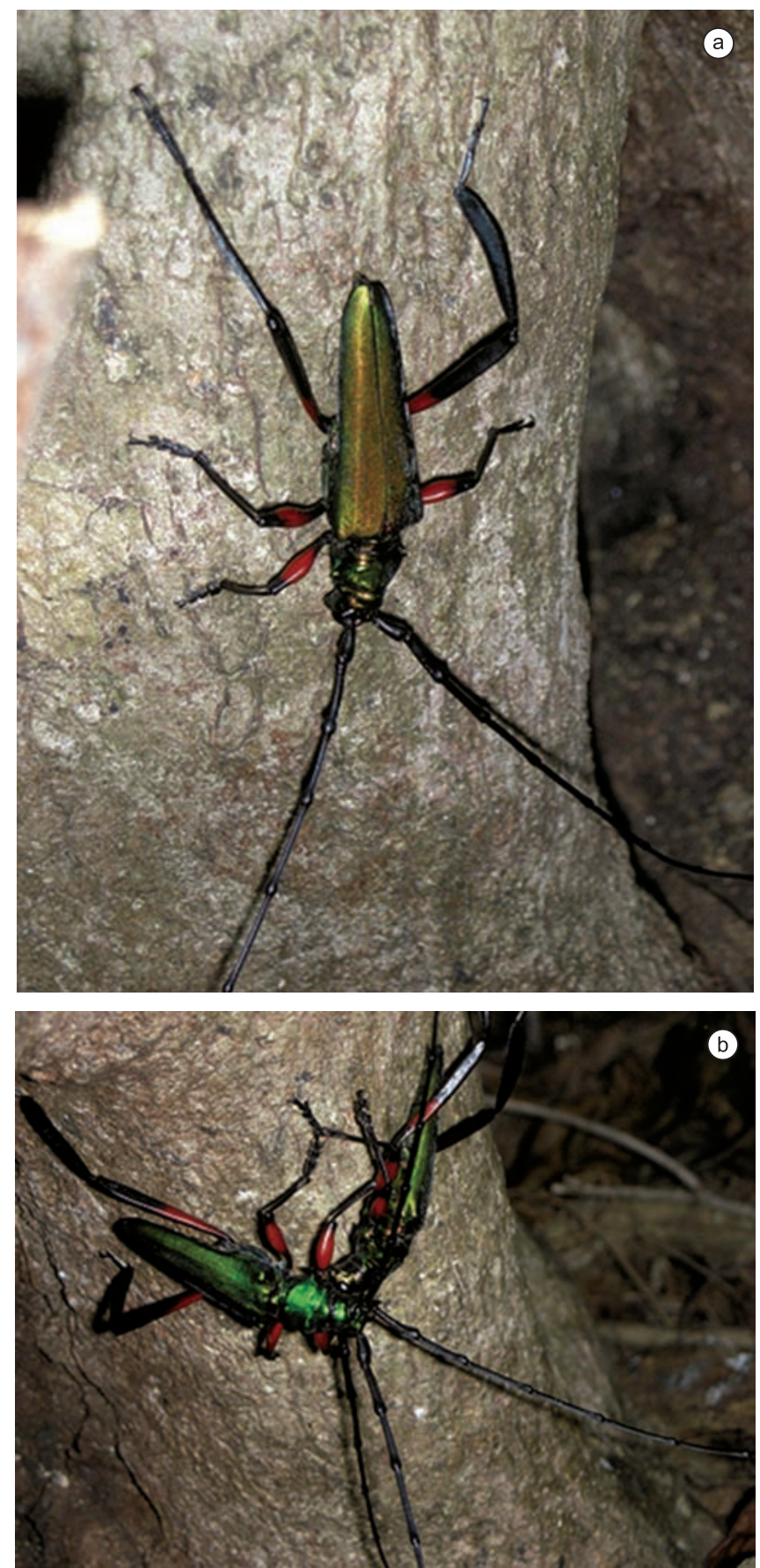

Figure 1. Schwarzerion holochlorum Bates involved in intense male-male competition for females, resulting in leg and antennal mutilations. Palo Verde Natural Reserve, Guanacaste province, Costa Rica.

Mutilated males did not leave the lek, suggesting the importance of scramble competition for females at this site.

Like in other cerambycid beetles (Linsley 1959), aggregating S. holochlorum are reported to stridulate and produce strong odors, presumably alarm pheromones which were shown to elicit dispersal flights (Greeney \& DeVries 2004). The arrival behaviour of males observed at the lek in the present study, suggests the possibility of pheromonal cues as a basis also for aggregating behaviour, but could also be explained by attraction to the site by volatiles from the tree. Most of the sense organs are found in the antennae (Linsley 1959), and the loss of such structures due to male-male interactions sug- 
gests some costs involved in this resource-based lekking system. As indicated by Møller \& Zamora-Muñoz (1997), the lack of antennal symmetry may also indicate a mating disadvantage following amputation. Hence, amputated males are likely to suffer costs other than just physical damage. The intense character of the male-male competition, the frequent amputations observed and the possible differences in mating advantages in differently sized and shaped males, call for further studies of individual costs and benefits in the mating behaviour of this species.

\section{Acknowledgments}

I am grateful to Sharon L. Shute, Natural History Museum, London, for species identification, H. F. Greeney (pers. comm.) for information about aggregating behaviour in this species, Virginia Kustvall for field assistance and anonymous reviewers for valuable comments on the manuscript.

\section{References}

FETTKÖTHER, R., GADI, V.P., REDDY, G.V.P., NOLDT, U. \& DETTNER, K. 2000. Effect of host and larval frass volatiles on behavioural response of the old house borer, Hylotrupes bajulus (L.) (Coleoptera: Cerambycidae), in a wind tunnel bioassay. Chemoecology 10(1):1-10.

GOLDSMITH, S.K., STEWART, Z., ADAMS, S. \& TRIMBLE, A. 1996. Body size, male aggression, and male mating success in the cottonwood borer, Plectrodera scalator (Coleoptera: Cerambycidae). J. Ins. Behav. 9(5):719-727.

GREENEY, H.F. \& DEVRIES, P.J. 2004. Experimental evidence for alarm pheromones in the Neotrophical longhorn beetle, Schwarzerion holochlorum Bates (Coleoptera: Cerambycidae). Coleopt. Bull. 58(4):642-643.
HANKS, L.M., MILLAR, J.G. \& PAINE, T.D. 1996. Body size influences mating success of the Eucalyptus longhorned borer (Coleoptera: Cerambycidae). J. Ins. Behav. 9(3):369-382.

LARSSON, F.K. \& KUSTVALL, V. 1990. Temperature reverses sizedependent male mating success of a cerambycid beetle. Func. Ecol. 4(1):85-90.

LINSLEY, E.G. 1959. Ecology of Cerambycidae. Ann. Rev. Ent. 4(1):99-138.

LÓPEZ-PANTOJA, G., NEVADO, L.D. \& SÁNCHEZ-OSORIO, I. 2008. Mark-recapture estimates of the survival and recapture rates of Cerambyx welensii Küster (Coleoptera Cerambycidae) in a cork oak dehesa in Huelva (Spain). Centr. Eur. J. Biol. 3(4):431-441.

MICHELSEN, A. 1963. Observations on the Sexual Behaviour of Some Longicorn Beetles, Subfamily Lepturinae (Coleoptera, cerambycidae). Behaviour 22(1-2):152-166.

MØLLER, A.P. \& ZAMORA-MUÑOZ, C. 1997. Antennal asymmetry and sexual selection in a cerambycid beetle. Anim. Behav. 54(6):1509-1515.

RAY, A.M., GINZEL, M.D. \& HANKS, L.M. 2009. Male Megacyllene robiniae (Coleoptera: Cerambycidae) use multiple tactics when aggressively competing for mates. Env. Entomol. 38(2):425-432.

WANG, O. \& ZENG, W. 2004. Sexual selection and male aggression of Nadezhdiella cantori (Hope) (Coleoptera: Cerambycidae: Cerambycinae) in relation to body size. Env. Entomol. 33(3):657-661.

ZEH, D.W., ZEH, J.A. \& TAVAKILIAN, G. 1992. Sexual Selection and Sexual Dimorphism in the Harlequin Beetle Acrocinus longimanus. Biotropica 24(1):86-96. 